\title{
EUTOMIA
}

Revista de Literatura e Linguística

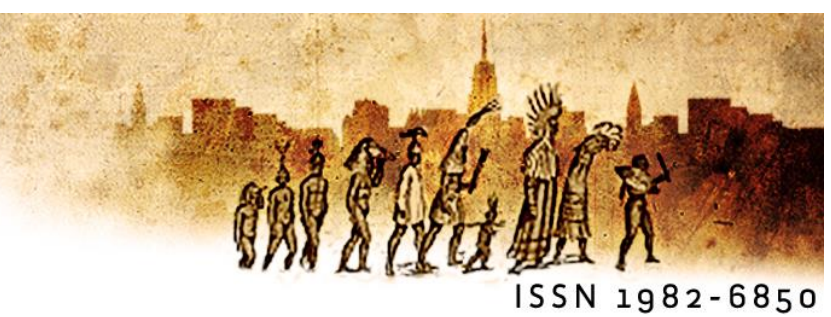

\section{Romance e subjetivação: a Grécia antiga como estudo de caso}

\author{
Pedro Dolabela Chagasi (UFPR) \\ Débora Gandra de Souzaii (UFPR)
}

\begin{abstract}
Resumo: Descreve-se algumas das condições sistêmicas que, na Grécia do início da era cristã, motivaram a subjetivação da temática ficcional no romance, gênero então emergente. Enquanto a épica e a tragédia traziam heróis lendários e dramatizavam problemas coletivos, o romance lidava com a vida prosaica, com consequências para a composição dos personagens, para a concepção de vida pessoal dos enredos, para a suas estórias de amor à primeira vista. Propõe-se que quatro elementos favorecerem essa passagem à subjetivação: o status da cultura grega no Império Romano, a influência da segunda sofística, a marginalidade do gênero no campo letrado, as tecnologias da escrita. Lança-se, ao final, a hipótese de que condições análogas ou semelhantes grosso modo se repetiriam nos contextos em que o romance voltaria a vicejar, espelhandose na concomitante subjetivação dos modos de leitura estimulados pelo gênero.
\end{abstract}

Palavras-chave: Teoria do romance, História do romance, Romance grego antigo.

Abstract: The article describes some of the systemic conditions that motivated the subjectivation of fictional themes in the Ancient Greek novel. While the epic and the tragedy presented legendary heroes and dramatized collective issues, the emerging genre of the novel dealt with prosaic life, with consequences for the composition of the characters, for the plots' conception of personal life, and for their stories of love at first sight. It is suggested that four elements favored that subjectivation: the status of the Greek culture in the Roman Empire, the influence of the second sophistic, the marginality of the genre in the literary field, the history of writing and the commercialization of written texts. In the end, it is hypothesized that similar conditions would roughly be present in later contexts where the novel reappeared, in line with the subjectivation of the modes of reading it came to stimulate. 
Keywords: Theory of the novel, History of the novel, Ancient Greek novel.

O romance e seus personagens: idealizados ou não, "realistas" ou não, "planos" ou "redondos", em comum eles vivem problemas, conflitos, tensões, alegrias pessoais. A palavra é essa: "pessoais". Suas estórias são individualizadas, subjetivadas; eles são figuras que vivem no enredo os seus próprios problemas - que sempre comportam, é claro, certo grau de tipificação que permitirá ao leitor compreender e julgar as suas ações e, quem sabe, sentir empatia pela sua condição. A intepretação do texto apela, pois, à experiência de vida pessoal de um leitor que também é, desse modo, subjetivado ao envolver-se afetivamente no conflito encenado: para estórias personalizadas, um leitor pessoalmente implicado. Da constatação desta característica predominante do romance este artigo pretende identificar algumas das condições que, no contexto inicial do seu surgimento no ocidente - a Grécia do início da era cristã -, iriam permiti-la, ou mesmo motivá-la.

Era uma Grécia mergulhada em narrativas - no mito, na épica, na tragédia, um cânone clássico que não era, em seu horizonte sincrônico, ficcional da maneira como hoje compreendermos o termo. Eram estórias baseadas em eventos e personagens então compreendidos como verdadeiros, no limiar turvo entre a história e a lenda em que certa dose (variável) de crença na representação permeava a relação do público com o representado, tal como hoje acontece, de maneira também variável e difusa, com o Novo Testamento. Segundo a definição de Gregory Currie (1990), as narrativas que integravam o cânone clássico eram majoritariamente "pseudoficções", i.e. produções que hoje se dão a ler como ficções, mas apenas sob o deslizamento do "pano de fundo" culturalizado que torna a nossa leitura tão diferente daquela que originalmente se fazia. Mas os romances gregos não eram "pseudoficções": em regra eles eram ficções, pura e simplesmente, cujos personagens, como em qualquer ficção, seriam conhecidas pelo leitor apenas na leitura do texto. Aparecendo tardiamente (o último dos romances conhecidos viria mil anos depois da primeira épica), com enredos que não se baseavam na mitologia, eles chegavam a exibir e tematizar ostensivamente a própria ficcionalidade, nos prefácios, nos enredos, na emulação de outros gêneros. E enquanto a épica desfilava heróis lendários e a tragédia dramatizava problemas coletivos - problemas da polis -, o romance lidava com paixões, traições, 
ciúmes, temas da vida prosaica, demarcando a sua diferença em relação à tradição letrada. O que teria fomentado essa passagem à personalização ou subjetivação da matéria narrativa? O que houve de especial naquela ambiência social que a teria motivado?

Não temos uma resposta precisa; a nossa abordagem é propositiva. Ela cumpre ademais um objetivo que não será tratado explicitamente, permanecendo como ideia de fundo: a proposição de que o quadro social que possibilitou aquela subjetivação da temática ficcional na Grécia antiga comportaria semelhanças com os quadros sociais em que o romance mais tarde vicejaria - no Japão medieval, na Europa moderna, na América Latina do século XIX... Trata-se de um exercício de história comparada do gênero, aqui iniciado com o foco restrito em um dos ambientes em que ele despontou. Esso objetivo de fundo explica porque certas características pertinentes exclusivamente ao contexto grego - como o novo tipo de religiosidade que, segundo Doody (1996), teria influenciado o processo em questão - não serão analisadas: se o objetivo de longo prazo é estabelecer semelhanças entre diferentes sistemas letrados, concentraremos a nossa atenção nas condições de produção e circulação da informação e do discurso.

Seguiremos duas frentes, distintas e convergentes. Primeiro veremos a subjetivação acontecendo no corpo das obras: na composição dos seus personagens, na concepção de vida pessoal implicada nos enredos, nas suas estórias de amor à primeira vista. Daí iremos observar certos aspectos do contexto social implicado: o status da cultura grega sob o Império Romano, as relações do romance com a segunda sofística, as implicações da marginalidade do gênero no campo letrado, as tecnologias de produção e circulação da escrita que deram suporte à sua produção.

Dos romances gregos que chegaram a nós, as primeiras produções (os chamados "romance de fronteira" ou "fringe novels") teriam aparecido no século I ou II a.C. A maior concentração viria no século II d.C, e estima-se que as obras mais tardias datam do século III. Nota-se que o gênero se desenvolveu majoritariamente sob o Império Romano - e a pax romana -, o seu declínio acompanhando o declínio de Roma. Qual foi a relação entre o ambiente do Império e o desenvolvimento do romance? Como mais tarde ocorreria na evolução de outras tradições romanescas no Japão do período Heian, na Inglaterra do século XVIII... -, ali havia estabilidade 
política, uma cultura letrada robusta, facilidade no transporte de produtos e na transmissão de ideias, elites letradas com tempo livre para a fruição da leitura (frequentemente na audição de textos lidos por terceiros), o contato com a alteridade cultural sob um fundo cultural comum. Como esses elementos contextuais então contribuíram para a subjetivação da temática ficcional no romance?

Medos, anseios, dúvidas e desejos, temas "menores" da vida privada ocupavam enredos que encenavam situações imprevistas na vida cotidiana, dramatizando problemas para os quais não havia soluções claras, colocando em perspectiva as normas morais à distância da ação prática. Na remissão à vida prosaica revolvia-se normas e valores dominantes, de forma crítica ou conservadora - tanto no romance grego, quanto nas manifestações subsequentes do gênero. Por "vida prosaica" não entendemos a representação da "vida comum de pessoas comuns", função afinal assumida, de maneira proeminente, apenas pelo romance moderno: no romance grego os heróis nem sempre eram "comuns", mas a sua condição nobre e idealizada não impedia que os seus problemas - por exemplo, os dilemas amorosos de jovens apaixonados, com suas crises de separação, traição, o dilema da castidade... fossem aproximáveis da vida pessoal do leitor. Esse é o ponto: tinha-se a remissão a dilemas, tensões e angústias que os leitores podiam aproximar das suas experiências e seus contextos pessoais de vida, nos quais eles poderiam imaginar-se implicados, ou que eles estariam livres para julgar, moral ou eticamente, a partir de parâmetros valorativos personalizados - provavelmente compartilhados, mas não necessariamente hegemônicos na polis.

Um exemplo pode ser visto numa cena do romance Quéreas e Callíroe, de Cáriton de Afrodísias:

Plagon respondeu com uma pergunta. "Há quanto tempo você acha que está gravida?". "Dois meses", disse Callíroe. "O tempo está do seu lado então. Você pode fazer com que pareça que a criança é de Dionisus, nascida aos sete meses". [...] "Me de tempo para pensar" disse [Callíroe], "A escolha é muito importante - minha castidade ou meu filho!". E Plagon aprovou isso também - não decidir as pressas, seja para um lado, seja para outro. "Há boas razões para escolher qualquer uma das opções: a lealdade de uma esposa de um lado, o amor de uma mãe do outro [...].

Callíroe subiu para o seu quarto e fechou a porta. Ela segurou o retrato de Quéreas no seu ventre. "Aqui estamos nós três" ela disse, "marido, esposa e filho. Vamos decidir o que é melhor para nós. Eu 
darei a minha opinião primeiro: quero morrer sendo a esposa de Quéreas, e de mais ninguém. Não ter nenhum outro marido - meu coração preza esse desejo além dos meus pais, do meu país ou do meu filho. E você, filho meu, qual a escolha que faz para si? Morrer pela ação de venenos, antes de poder ver a luz do dia? Tornar-se um pária, junto com a sua mãe, e talvez não ser digno nem mesmo de um funeral? Ou viver, e ter dois pais - um comandante na Sicília, outro em lonia? [...] O seu voto é contra o meu, meu filho: você não irá aprovar a nossa morte. Vamos perguntar ao seu pai também. Não, ele já se pronunciou: ele veio pessoalmente em meus sonhos e disse: 'Confio o meu filho a você'. Chamo você como testemunha, Quéreas - é você que está me dando como esposa à Dionisus. (CHARITON, 1986, p.48-9. Tradução de Débora Gandra de Souza)

Essas questões morais são pessoais: a cena não se dirige à polis e suas tensões atuais ou constitutivas, mas a um conflito íntimo envolvendo o compromisso matrimonial, uma gravidez problemática, a traição. Callíroe evoca o filho e o marido, e não os deuses ou as leis ao imaginar uma solução que envolveria, afinal, apenas aquelas três pessoas. Seria uma solução improvisada, uma solução ad hoc para um problema imprevisto - e que era, como conflito feminino (a tensão entre a lealdade da esposa e o amor da mãe), marginal ao debate público. Tal representação do prosaico distinguia o romance entre os gêneros letrados, especialmente porque, com ela - ou para ela - viriam os seus personagens mutáveis envolvidos numa concepção peculiar da vida individual, e muitas vezes implicados em estórias de amor mútuo à primeira vista - hoje um clichê banal, mas cuja novidade inicial merece ser bem discernida.

Para encenar dramas pessoais o romance construía personagens comparativamente mais flexíveis do que o cânone clássico. Na épica os personagens se definiam por alguma característica saliente (o "astuto" Odisseu, o "sábio" Nestor); no drama, personagens aparentemente mais complexos pouco variavam psicologicamente no decorrer da ação (no caráter, na personalidade, no temperamento, em suas vontades e crenças...), o que acabava por selar o destino trágico - pela "teimosia" do Édipo de Sófocles, a "racionalidade" do Cadmo d'As Bacantes de Eurípides... Mas no romance os protagonistas podiam superar as suas próprias qualidades ruins: eles viviam transformações, às vezes indesejadas, às vezes intencionais. Quéreas, marido de Callíroe, exemplifica o herói que superava os próprios erros iniciais ao passar a se orientar pelas virtudes imutáveis que, como um herói épico, ele também possuía: a sua lealdade à esposa, o seu valor excepcional 
como guerreiro, a sua inteligência e habilidade oratória (ao enfrentar Dionisus no julgamento que determinaria quem era casado com Callíroe) seriam qualidades que, ao final, Ihe permitiriam superar o ciúme doentio que, no início da trama, fizera-o atacar Callíroe violentamente. As provações que ele enfrenta ao longo do enredo são uma tentativa de rever a sua amada e uma penitência pelo ataque que ele cometera, $\mathrm{e}$ o apoio em suas virtudes heroicas é um corretivo contra as suas falhas humanas - mas aqueles qualidades não apagam essas falhas iniciais; durante o julgamento, os defensores de Dionisius apontam que Quéreas não é confiável, dizendo para Callíroe: "Escolha seu benfeitor, seu salvador, não o homem que matou você. E se Quéreas tiver outro ataque de raiva?" (CHARITON, 1986, p.89. Tradução de Débora Gandra de Souza). Ou seja, Quéreas é construído como um marido violento e irascível e um herói virtuoso, características tipificadas que seriam balanceadas no julgamento que, ao final, o mostraria como um marido digno de Callíroe pela sua manifestação de arrependimento e desejo de reparação. Ao revolver esses sentimentos - que, genericamente colocados, seriam familiares ao universo de vida do leitor -, encenando as suas implicações para a mudança do comportamento do protagonista, o enredo tanto preservava a noção clássica da fixidez (a imutabilidade) do "caráter" do herói, quanto indicava que o reequilíbrio dos vieses positivos e negativos daquele "caráter" poderia conduzir à sua mudança. E note-se que isso era ali permeado por uma inversão das posições tradicionais de gênero: era o marido quem devia se mostrar digno da esposa, reparando falhas de personalidade que ele reconhecia em si mesmo, mas que ele amadurecera o suficiente para compreender a necessidade de reprimi-las.

Personagens mutáveis também em Leucipe e Clitofonte, de Aquiles Tácio: no início Leucipe é uma jovem luxuriosa, que aceita os esquemas de Clitofonte para se encontrarem à noite em seu quarto e só não perde a virgindade por acaso (a sua mãe acorda de um pesadelo e os interrompe). Depois de fugir com o amado, de ser separada dele e passar por várias desventuras, ela sonha com Ártemis, que promete protegê-la e entregá-la como noiva a Clitofonte desde que ela se mantivesse virgem. Então Leucipe se torna uma heroína da castidade, defendendo a sua virgindade do desejo de Clitofonte e dos seus próprios desejos, inclusive ao ser sequestrada por piratas e vendida como escrava a um prostíbulo - ao final, ela é reunida a Clitofonte e 
se casa com ele, conforme prometera a deusa. É uma transformação de crença e de comportamento sugestionada pela divindade, mas uma transformação mesmo assim: no romance grego os personagens se transformam, no decorrer da aventura, ao se apaixonarem, ao arrependerem das suas ações, ao serem lançados ao perigo enfrentando piratas, sendo vendidos como escravos... -, ao entrarem em contato com a alteridade (de maneira amistosa ou conflituosa), e também pela intervenção sobrenatural. Decerto nem todos personagens eram assim: se Quérreas era orientado por suas qualidades e defeitos imanentes, Calírroe preservava as suas virtudes morais intocadas no decorrer da desventura; Dafne e Cloé não mudariam moralmente, mas pela descoberta e vivência do amor. Seja como for, representar os personagens na vivência de algum tipo de transformação psicológica eram uma novidade do romance, inscrita na tematização de problemas da vida privada daqueles jovens que lidavam com situações complexas da maneira como podiam. Eram figuras investidas de um senso pronunciado de self, em geral indicado por descrições que pontuavam a diferença ontológica - e eventual contraste - entre a sua psicologia e a sua fisicalidade (a apresentação exterior): em As Efesíacas, de Xenofonte, pontua-se que, com o passar dos anos, crescera a beleza do corpo de Habrócomes e a bondade de sua alma; em $O$ Asno o corpo de Lucio se metamorfoseia, mas a sua consciência permanece humana, o que reforça a sua individualização - em lugar da sua generalização ou alegorização.

Tudo isso era permeado por certo tipo de teoria da vida. Numa narrativa baseada no mito os acontecimentos são infundidos com significados de abrangência coletiva: cada evento ilumina as motivações das personagens projetando um significado amplo sobre a vida coletiva. Mas nos romances gregos era comum que a sequência episódica de eventos - de certo modo antecipada na Odisseia - enredasse a linearidade causal em segmentos que não seriam necessários para o desfecho da trama, mas que eram interligados na medida em que iam se sucedendo na sequência de aventuras inesperadas que, ao final, se conectavam cronológica e causalmente na definição do enredo. Essa era a forma de um mundo ficcional governado pela Týkhe (sorte, fortuna), em que o inesperado podia a qualquer momento mudar a direção da vida. Como elemento estruturador do enredo, a Týkhe (em muitos casos aliada ao Eros) construía um mundo aparentemente incoerente, em contraste com a coerência 
do mito: nem os personagens nem os leitores podiam prever o que viria em seguida, sendo surpreendidos por acontecimentos regulados pelo acaso e não pela necessidade, o que mitigava a universalização dos episódios (como símbolos de algo que os transcendesse).

Outro código importante desenvolvido pelo gênero foi o amor mútuo à primeira vista. Os protagonistas comumente eram um casal de jovens de alta classe, belos, inteligentes e virtuosos, que se apaixonam simultaneamente no instante em que seus olhos se cruzam - são acometidos pela doença do Eros, cuja única cura é a própria pessoa amada. Não se tratava do amor unilateral, disseminado desde o período arcaico com as suas posições bem definidas e desiguais do amante (erastes) e do amado (erômenos), em que o mais velho, experiente e ativo na aproximação buscava e seduzia e o outro que, mais novo, inocente e passivo, fugia ou era seduzido. Tal versão do amor apareceria, no tratamento do amor heterossexual e homossexual, na épica, na bucólica, na elegia, na lírica - mas não no romance. Ali haveria outro tipo de representação, que tampouco se encaixava na tradição platônica que associava o amor à apreciação e/ou à necessidade da beleza - mas só se deseja o que não se tem e, nessa tradição, o amor era uma distração ou degradação a ser expurgada; o ideal seria direcionar a mente para o divino, distanciando-se do mundo material para amarse o belo "como tal", ou "em si mesmo". No romance tudo era bem diferente: lá o amor era igualitário, recíproco e, na maioria dos registros, simultâneo. Os amantes eram iguais social e intelectualmente, e tinham a mesma idade e o mesmo status social. O amor não era algo a ser superado em busca de uma ascensão filosófica, mas um estado estável e benéfico: ainda que ele inicialmente acometesse os protagonistas como uma doença, ele ao final curava a doença quando os protagonistas se reuniam.

Muda também a função do amor no enredo. Ao colocar a vida privada em destaque, o romance distanciava as escolhas dos personagens do controle moral normativo pelo estado e pela família, de grande importância nos gêneros clássicos onde o único modo moralmente aceito de confrontar as duas forças era opor uma à outra, como em Antígona. No romance, porém, uma personagem como Callíroe poderia dizer: "Não ter nenhum outro marido - meu coração preza esse desejo além dos meus pais, do meu país ou do meu filho"... (CHARITON, 1986, p.49. Tradução de Débora Gandra de Souza). Pois muitas vezes eram a polis e a família que ameaçavam 
a concretização do amor, e contra as suas imposições os heróis tomavam as suas decisões: em As Etiópicas, Caricléia e Teágenes abandonam um e outro sem hesitação; o chamado do amor era maior do que a lealdade às próprias origens. Decerto a fuga dos amantes (quando a família se opunha à sua união) não era sem precedentes nos gêneros clássicos: ela era comum nas comédias de Menandro, e mais tarde em Plauto e Terêncio. Mas lá o amor surgia e se desenvolvia na ambiência do lar, e no final os jovens a ele retornavam, pedindo a aprovação dos pais. No romance, nem a aprovação nem o perdão eram necessários: ao fugir, Caricléia e Teágenes obedeciam a um chamado maior do que a família e a polis - a sua lealdade recíproca superava qualquer outra.

Tendo apresentado a subjetivação da temática ficcional no romance em algumas das suas características mais frequentes, passamos agora à pergunta principal deste artigo: o que sabemos sobre o contexto em que ela ocorreu?

Sabemos que o Império aumentou o contato entre as culturas do Mediterrâneo, gerando uma circulação mais intensa de produtos e ideias e um aumento na complexidade nas redes de interação e transmissão da informação. Especificamente o lugar de surgimento do romance - a porção oriental do Império era multiétnico e multicultural, mas ele também mantinha a cultura grega clássica como fundo cultural comum, no topo do cânone erudito. Todo o Império era helenizado nalguma medida, pois a cultura grega estava na base da educação da sua elite letrada; desse modo, havia um circuito erudito culturalmente diversificado nas várias localidades do Império, mas unificado pela helenização. Esse ambiente ao mesmo tempo multicultural e culturalmente unificado - greco-romanizado fomentaria a elaboração de códigos artísticos estética e tematicamente transculturais, interpretáveis e admissíveis em diferentes lugares ao apelarem à erudição compartilhada. Isso constituiria para a produção letrada um público ampliado, culturalmente heterogêneo e unificado, além de variado em seus graus de erudição. A comunicação com esse público favoreceria gêneros - como o romance que se relacionassem com o cânone de maneira flexível, remetendo aos elementos mais populares do seu repertório sem se pautar pelas apropriações prevalecentes na "alta cultura", e desse modo acessando públicos de várias formações. Em suma, a heterogeneidade imanente a um público dotado de referências comuns motivaria a 
exploração de temas e formas não tradicionalizadas apenas em lugares precisos; entre os temas que tinham apelo em qualquer lugar estariam o amor, a traição, a aventura, a incidência do acaso e suas implicações na vida comum - o domínio do prosaico, em suma.

No Império o contato com a alteridade transcorria sob um quadro geral de relativa estabilidade política. Essa mistura de diversidade e estabilidade, a relativa normalização e pacificação das trocas culturais favorecia a circulação de interpretações discrepantes do real. Soma-se a isso que, se o mundo prosaico em regra conhece tensões (e desorientações) não previstas pelo saber institucionalizado (o discurso religioso, filosófico, legal), cujo debate costuma lento e autorreflexivo, a ficção é rápida ao remeter a problemas urgentes: o romance é mais aberto, poroso, flexível no tratamento do presente do que o pensamento sistematizado (sempre equacionado, por definição, num momento anterior da história social). E então havia a segunda sofística, que retomava a cultura clássica grega de maneira autorreferencial, talvez o primeiro movimento literário autoconsciente do ocidente (no entender de Margaret Ann Doody (1996). Famosos pela performance retórica, os sofistas alcançaram influência no direito, na política, na diplomacia, mantendo o cânone grego - de uma era clássica imaginária, representativa de uma identidade grega imaginada como referência na construção do discurso. Esse último aspecto é relevante, pois a remissão a uma "cultura clássica" que se tornara autoconsciente sob um Império estrangeiro que dominava o seu território, mas que tinha pela sua cultura uma grande reverência, servia como instrumento de afirmação tanto da própria tradição cultural, quanto da Grécia contemporânea: assim o recurso ao cânone envolvia o manejo criativo do seu repertório, para cumprir a nova função de contraposição ao sentimento de decadência do território colonizado.

Essa ancoragem da performance retórica no helenismo clássico se dava à revelia da origem do orador, muitas vezes asiático ou africano, fazendo com que a retomada do cânone fosse acolhedora aos estilos, ornamentações e modos retóricos das culturas vizinhas. Enquanto os retores "aticistas" buscavam restaurar um (idealizado) dialeto ático mediante a imitação "purista", sóbria e reservada, dos autores atenienses, os "asianistas" tinham maior fervor teatral - na prática, vários sofistas transitavam entre os dois polos, exibindo características de ambos: era o 
caldeirão cultural do Império, que rotinizava um uso flexível da tradição letrada numa prática oratória marcada pela versatilidade das estratégias de apresentação e envolvimento do público. No limite, essa prática mitigaria a preocupação com a delimitação epistemológica da verdade ao borrar a distinção entre a persuasão e o convencimento: a persuasão do público era a meta, e não a fundamentação racional do argumento. Essa relação com a verdade, que perdia a pretensão à atemporalidade para emergir da fricção com o contexto de relação com o público, seria semelhante ao tipo de juízo moral sugestionado pelo romance - sempre específico ao contexto encenado na trama, em diálogo com os "horizontes de expectativa" do público visado (v. GRAHAM, 1993).

Sabe-se que alguns romancistas eram sofistas, e que boa parte deles não vinha da Grécia, mas de outras regiões do Império (especialmente da Ásia Menor). Não por acaso o romance grego compartilhava com a segunda sofística certos aspectos formais, retóricos, temáticos e performáticos: o público do sofista pode ter coincidido com o público do romancista, incluindo jovens das aristocracias locais que se tornavam pupilos dos sofistas, gente em busca de entretenimento, porções da elite erudita. Como figura pública o sofista estava mais próximo de um autor individualizado do que o antigo membro de uma escola filosófica, tendo a sua fama atrelada ao seu nome (podendo chegar ao estrelato). O seu palco se incorporava à vida pública de várias maneiras - nas atividades privadas das elites, nos tribunais, no debate político. Além da escrita e da performance oral, os sofistas eram professores, advogados, embaixadores, celebrizando-se nas suas cidades nativas ou adotivas, e nas tantas outras pelas quais eles transitavam. Eles eram treinados para manejar uma gama diversa de temas e formas de elocução, e exercer um domínio textual que facilitasse a manipulação de vários gêneros e práticas textuais: os exercícios incluíam a narração, a descrição (écfrase), a argumentação (prova e refutação), a comparação, o elogio e a acusação, com incentivo para o experimento individualizado com o repertório clássico, prática que flexibilizava a tradição letrada ao direcioná-la ao público aberto. O treinamento também previa a capacidade de contar estórias mitos, fábulas, feitos históricos, ou imitações de qualquer um deles - e a capacidade de questionar narrativas - por exemplo, pela refutação ou asserção do mito: o aluno podia ser treinado para afirmar que não se podia saber se Calipso realmente existira, 
ou que era improvável que Zeus se rebaixasse a dormir com uma mortal, ou que Odisseu jamais precisaria da ajuda de Palas Atena... Na sedução da audiência durante a performance o poder de refutação podia ser uma boa estratégia, afirmando-se a contrapelo do senso comum tradicionalizado.

Não parece ter havido causação direta entre as duas formas discursivas; fragmentos de papiro revelam romances escritos antes da segunda sofística. Mas aqueles deslizamentos da verdade na sofística - a verdade como um efeito do discurso -, operados em formas discursivas flexíveis e abertas à mistura de gêneros, teriam certa afinidade com o romance emergente e sua abordagem de problemas localizados nas lacunas do saber instituído, não raro mediante a referência a gêneros e convenções formais herdados da tradição letrada. Tal como na retórica, também no romance uma performance conduzida pelo manejo das convenções letradas apelava a noções socialmente compartilhadas - mitos, crenças, valores - para energizar o envolvimento do público nos problemas dramatizados (ainda que, num gênero escrito como o romance, as formas e os temas do discurso não pudessem dialogar especificamente com as expectativas de uma audiência restrita, fisicamente presente).

Se esse relaxamento da relação com a verdade e a tradição discursiva facilitava - ou legitimava - o apelo do romance à temática prosaica, o mesmo se pode dizer da condição marginal do gênero dentro do campo letrado. De um lado, a sua falta de institucionalização tornou-o desprovido de uma teoria formalizada: ele não foi sequer nomeado na Antiguidade. Mas não ser regrado por tratados poéticos tornaria-o ágil e flexível; ter uma posição inferiorizada em meio a uma "alta cultura" que tinha a poesia como modelo de excelência liberava-o para a exploração de temas e formas. Contribuía para tanto também a sua aparente carência de função. O romance grego enfrentou o mesmo desafio que se imporia ao gênero em suas várias tradições: justificar a sua própria leitura, que parecia ter como único (e "baixo") objetivo o lazer. Muitos dos proêmios procuravam explicar a função do gênero, como em Das narrativas verdadeiras de Luciano - que buscava dignificá-lo sob a acusação, que Luciano transformava em elogio, do prazer, leveza e facilidade da sua leitura:

Como os atletas e os que se dedicam ao cuidado do corpo não se preocupam só com a boa forma e com exercícios, mas também com o descanso no momento oportuno (...), assim também, para os que 
se esforçam nos estudos, julgo ser conveniente, após muitas leituras difíceis, relaxar a mente e torná-la mais vigorosa para o trabalho seguinte. Para eles, representaria um descanso conveniente entregarem-se a leituras do presente tipo, as quais não só, com bom humor e graça, proporcionam simples diversão, mas também apresentam alguma reflexão que não é indigna das Musas. Eu suponho que assim eles considerarão também essas histórias. (BRANDÃO, 2005, p. 167-8)

Um elemento que tanto sinalizava quanto impunha marginalidade ao romance era o hibridismo formal das suas obras, que manipulavam elementos de vários gêneros: proêmios típicos da historiografia, temas da epopeia, julgamentos e cenas de tribunal, estratégias de composição inspiradas no drama, discussões filosóficas e écfrases retóricas, além de citações de obras desses gêneros. Meta-letrado, o romance previa um leitor capaz de reconhecer os gêneros mimetizados e inferir sentidos do texto a partir da diferença entre os usos convencionais daqueles gêneros e as referências que lhes eram feitas. Já os enredos apresentavam um mundo letrado, habitado por leitores: o Lucio de O Asno era um escritor que desejava tornar-se personagem de livro, Callíroe se despediria da rainha da Pérsia pedindo que ela lhe escrevesse... Nesse ambiente letrado, compartilhado pelos personagens e seus leitores, a mistura de gêneros e a alusão literária davam organização às remissões das obras às normas sociais que elas tematizavam. O romance tensionava tanto as normas quanto as alusões literárias a que ele apelava para tematizá-las: a alusão a outros gêneros colocava (ou não) a discussão ética sob as convenções que a tradição letrada costumava conferir-lhe, para agregar aos temas abordados novas ou velhas camadas de significado, que oscilariam da confirmação do enquadramento ético tradicional ao seu questionamento.

Toda essa comunicação com um público ampliado era potencializada pelo aumento do alcance da mídia escrita. É sabido que na Grécia o letramento não esteve sob o monopólio de alguma classe administrativa ou religiosa (como em outros Impérios da Antiguidade), o que por si aumentaria o seu uso e exploração. Os materiais disponíveis eram o papiro e, mais tarde, o pergaminho: o papiro era produzido a partir da planta encontrada no delta do Nilo e tinha a sua distribuição regrada por acordos comerciais com o Egito; se a sua disponibilidade favoreceu a difusão da escrita, a sua relativa dificuldade de obtenção preservaria, no entanto, a 
força da tradição oral. Assim permaneceram as coisas até que Eumenes II (197 - 159 a.C.) construísse em Pérgamo uma biblioteca que competiria com a de Alexandria e, tendo enfrentado restrições na compra de papiro, viesse a incentivar o uso de pergaminho, chegando a estabelecer um monopólio de produção.

Foi nesse contexto de crescimento do comércio privado de livros que, ao que parece, surgiram os "romance de fronteira" ou "fringe novels"; o Romance de Alexandre, de Calístenes, teria sido escrito em torno do século 2 a.C. (a datação é hipotética). Com o tempo, o uso do pergaminho aumentaria a quantidade de texto incluído em cada volume, que podia abrigar uma composição bem mais extensa que o rolo de papiro. O seu formato também facilitava o retorno a informações anteriores do texto, o ir e voltar da leitura que aumentava a capacidade mnemônica do leitor, permitindo a construção de textos com maior número de personagens, de ações, e mais ricos em detalhes - o que teria implicações para o aumento da densidade e complexidade dos enredos do romance entre os séculos I e IV d.C. (v. INNIS, 1986)

É sabido que a transição entre a oralidade e o letramento nunca levou à substituição pura e simples da oralidade. A Grécia teria vivido o primeiro momento na história humana em que uma cultura letrada altamente interiorizada se autodistanciou - ou mesmo se chocou - com a cultural oral (ONG, 2002, pg 24i HAVELOCK, 1986, pg 87), de maneira progressiva: no começo do século VI a.C. as ordens judiciais gregas deixaram de ser orais e se tornaram documentos escritos, e com isso o número de leitores aumentou; na segunda metade do século quinto canções dos aedos já circulavam em manuscritos, e dramas eram transcritos para venda após a primeira apresentação. O contraste foi se firmando, pois uma cultura oral não lida tão bem com categorias artificiais abstratas (como conceitos filosóficos ou figuras geométricas), nem com a racionalidade fria da lógica formal, ou com a prática da análise ou autoanálise sistematizada: esses modos de pensamento estarão mais à vontade no registro escrito. E mesmo que a produção de livros fosse limitada, a circulação da escrita ia crescendo: no século III a.C. foi fundada a biblioteca de Alexandria, que em 285 já possuía 20.000 exemplares (reunidos sobretudo para a preservação e conservação, e não para a circulação do conhecimento). A escrita foi ganhando espaço; na era alexandrina, grandes coleções e bibliotecas viraram símbolo de bom gosto, poder e respeitabilidade. Ptolomeu II (309-246 a.C.) estabeleceu uma 
política de subsídios que barateava o custo do papiro no Egito e encarecia a sua exportação, o que fez dele a base do sistema administrativo (e das grandes bibliotecas) do Egito, mas também tornou o preço do rolo na Grécia duas ou três maior que no Egito - daí a reação de Eumenes II em Pérgamo.

A importância política e social da escrita crescia ininterruptamente, portanto, e em meio a esse processo surgiu o romance. As formas narrativas que primeiro sucederam o predomínio da oralidade haviam preservado linguagens e processos de pensamento da cultura oral; boa parte da literatura clássica grega nascera de transcrições (ou transcriações) da oralidade para a escrita, que então atuava como registro e prolongamento de uma cultura que permanecia oralizada. Esse senso de oralidade primária pode ser observado tanto em aspectos básicos da literatura clássica grega (como na escrita em verso), quanto nalguns dos seus traços mais complexos, mas ainda característicos da mentalidade oral (como o dinamismo das falas e ações, ou o caráter situacional - e não proposicional ou reflexivo - dos usos da linguagem). (HAVELOCK, 1986, pg 90-94) Mas o romance, vindo tardiamente, nasceu escrito. Foi o único gênero letrado que nasceu na Grécia como texto; ao contrário da épica ou do drama, ele não possui um precedente oral. Várias das suas características dependem da escrita, não só como suporte, mas como tecnologia capaz de organizar o pensamento e estruturar a mente a humana. Para o que nos interessa neste artigo, as personagens das narrativas que vinham da oralidade eram heroicas não apenas por "idealismo" ou "didatismo", mas também por razões mnemônicas: "memoráveis", seres extraordinários dão saliência aos seus modos próprios de organização da experiência, adquirindo exemplaridade não apenas pela qualidade das suas ações, portanto, mas pelo simples fato de que as suas ações eram facilmente lembradas por um grande número de leitores e ouvintes. (ONG, 2002, pg 69-70) Somente quando a escrita altera a estruturação do pensamento, permitindo a relação prolongada com personagens mais próximos do "comum", mas cuja mentes e comportamentos o leitor passaria a conhecer intimamente, apenas então a narrativa giraria em torno dessas figuras menos extraordinárias, mas que se davam a conhecer pelo contato prolongado com o texto.

Em suma, a difusão do romance coincidiu com a difusão e influência progressiva da escrita, que aumentaria a influência da cultura grega no Mediterrâneo. 
Livros foram produzidos em escalas sem precedentes entre os séculos II e I a.C.: nascia a prática da editoração, com seus escravos treinados como copistas, revisores e bibliotecários e um comércio intensificado de livros. Vários papiros contendo fragmentos de romances foram encontrados no Egito, levando a crer que a sua leitura era popular do século II a.C. em diante. Já no ambiente do Império Romano foram encontrados mosaicos retratando protagonistas de romances, sugerindo a amplitude do público envolvido com o gênero - naquele ambiente de aquecimento da circulação comercial da escrita, em sua relativa autonomia quanto à política e ao saber institucionalizado.

E então, como essas condições contextuais favoreceram a remissão ao prosaico no romance grego? Qual seria a correlação entre a ambiência cultural do Império (especialmente em sua porção oriental) e a emergência da personagem romanesca?

Uma resposta simples é identificar na movimentação de pessoas, na lida frequente com a alteridade cultural de maneira grosso modo pacificada, na circulação intensa da informação, na ambiguidade de um cânone erudito afirmado performativamente de maneira personalizada e, nesse mesmo gesto, fragilizado em sua autoridade normativa, nas escolhas de autores que circulavam pelo território devendo fazer-se entender por públicos de formações e gostos sempre parcialmente diferentes, nas possibilidades de acúmulo e minúcia da informação oferecidas pelo pergaminho, nas possibilidades de circulação social dos textos oferecidas pelo comércio do livro, é possível identificar nessa somatória de condições um campo cultural aberto à ocupação pela iniciativa individual pelo estímulo à individualização da escrita, da oratória, da reflexão especulativa. Que público esse campo teria constituído? Ou melhor: que público constitui aquele campo e foi por ele constituído numa relação de feedback em que autores e leitores se estimulavam reciprocamente? Performances individualizadas, espectadores seletivos nas suas preferências; pensamento individualizado para um público que se habituava a pensar individualmente; manejo personalizado das convenções culturais para um público que lidava com elas mais livremente... O embrião de uma sociedade de indivíduos, então, nem de longe parecida com o individualismo moderno, mas comparativamente regida por modos mais subjetivados de pensamento, expressão e ação - num quadro 
fomentado pelo letramento, em seu estímulo ao pensamento crítico. Culturas orais têm certa tendência ao conservadorismo: a oralidade favorece o tradicional e o familiar tanto no conteúdo quanto no estilo das produções narrativas, pois a necessidade da memorização impõe que o saber se firme na repetição, através das gerações, de formas facilmente memorizáveis e repetíveis - é necessário estabilidade para que a cultura não perca coerência, e certo senso de economia formal e informacional para que a informação não se perca e a repetição seja efetiva. (ONG, pg 42-46) Como resultado, no registro oral a crítica se revela custosa: a adição de novas informações transcorre de maneira lenta, cuidadosa, provocando a perda de parte da acumulação cultural anteriormente em circulação. Em contraste, a escrita favorece a inovação ao aumentar as possibilidades de armazenamento da informação, permitindo o acúmulo de conteúdos não diretamente relacionados com o já familiar e mnemonicamente acessível. A escrita favorece, em outras palavras, a produção, disseminação e acúmulo da diferenciação cultural, incluindo respostas inovadoras às inovações propostas. (ONG, pg 29-30, pg 72; HAVELOCK, pg 109 - 110) Há certa correlação entre o aumento do letramento e a difusão da diferenciação cultural produzindo um terreno fértil, afinal, para a emergência da narrativa ficcional escrita que convencionamos chamar de "romance".

Aí volta a pergunta: teriam sido semelhantes as condições de surgimento do gênero em épocas e locais posteriores? Isso nos demandará mais pesquisa, mas já a Espanha dos séculos XVI e XVII, a Inglaterra dos séculos XVII e XVIII e o Brasil do século XIX nos parecem semelhantes nos seus processos de súbita intensificação (e variação) da informação em circulação, e de aceleração da complexificação social. Pode-se dizer o mesmo do Japão do século $X$ e da China imperial, cujas tradições romanescas vicejaram à distância do Ocidente? Ainda não sabemos. Mas é possível que, pelo menos no Ocidente, a correlação entre aqueles processos sociais de larga escala e a subjetivação da representação ficcional tenha se repetido outras vezes. Voltaremos a isso futuramente.

\section{Referências Bibliográficas}

BRANDÃO, Jacyntho Lins. A invenção do romance. Brasil, UNB, 2005, 291 p. 
CHAGAS, Pedro Dolabela, OKIMOTO, Mariana. "O conceito de romance e o romance na história". Brasil, Eutomia, UFPE, volume 1, número 18, p. 20-41, 2017.

CHARITON. Chaereas and Callirhoe. In: REARDON, B. P. Collected Ancient Greek Novels, p. 17-124.

CURRIE, Gregory. The nature of fiction. Cambridge: Cambridge University Press, 1990, 235P.

DOODY, Margaret Anne. The True Story of the Novel. Estados Unidos, Rutgers University Press, 1997, $610 \mathrm{p}$.

EURÍPIDES. As bacantes. Tradução de Trajano Vieira. 2ed. Brasil, Perspectiva, 2014, $200 \mathrm{p}$.

GRAHAM, Anderson. The Second Sophistic. Inglaterra, Routledge, 1993, 307p.

HAVELOCK, Eric A. The muse learns to write. Estados Unidos, Yale University Press, $1986,144 \mathrm{p}$.

INNIS, Harold A. Empire and Communications. 5ed. Canadá, Press Porcepic Ltd, 1986, $184 \mathrm{p}$.

PAVEL, Thomas G. The Lives of the Novel: A History. Estados Unidos, Harvard University Press, 1986. $190 \mathrm{p}$.

REARDON, B. P. Collected Ancient Greek Novels. Estados Unidos, University of California Press, 1989. 827 p.

SOFOCLES. Antígone. Tradução de J. B. de Mello e Souza. Brasil, Clássicos Jackson, 2005. $89 \mathrm{p}$.

. Rei Édipo. Tradução de J. B. de Mello e Souza. Brasil, Clássicos Jackson, 2005.

$115 \mathrm{p}$

\footnotetext{
i Pedro Dolabela CHAGAS, prof. Dr.

Universidade Federal do Paraná - UFPR/CNPq

Departamento de Literatura e Linguística (DELLIN)

E-mail: dolabelachagas@gmail.com

ii Débora Gandra de SOUZA

Universidade Federal do Paraná (UFPR)

Bolsista PIBIC-UFPR/CNPq

E-mail: debgandra@hotmail.com
} 